\title{
Geoeducational Value of Quarries Located Within the Małopolska Vistula River Gap (E Poland)
}

\author{
Grzegorz Gajek $^{1}$ (D) - Wojciech Zgłobicki ${ }^{1}$ • Renata Kołodyńska-Gawrysiak ${ }^{1}$
}

Received: 8 November 2018 / Accepted: 6 August 2019/Published online: 26 August 2019

(C) The Author(s) 2019

\begin{abstract}
Formal and non-formal outdoor learning or field education is the most effective form of interpretation and promotion of geoheritage. Quarries make it possible to look back at the geological past of our planet, and, in many regions, they are the only places where we can observe the exposed bedrock. In E Poland, a considerable number of quarries are located within the area of the Małopolska Vistula River Gap. Herein, Upper Cretaceous, Palaeocene and Miocene marine rocks and Pleistocene sediments of varying origin were quarried. The location of quarries in the proximity of larger and smaller towns enables organising short school trips and conducting geography field classes. What is more, the importance of the town of Kazimierz Dolny, a popular tourist destination located in the northern part of the study area, provides opportunity for enriching the existing "traditional" tourism with offers of geotourism. In the study, the geoeducational value of 53 quarries was assessed by means of a method developed by the authors. This takes into account 20 criteria belonging to four groups of values (scientific, educational, tourist and functional). Additionally, significance was assessed from the perspective of three different audience groups (pupils, university students and non-specific tourists). The assessment made it possible to identify the spatial variation of the geoeducational potential of the quarries, as well as their strengths and weaknesses. Measures were also identified to be taken in the future in order to increase the currently limited use of the quarries for educational purposes.
\end{abstract}

Keywords Education · Geoheritage $\cdot$ Geopark $\cdot$ Quarries

\section{Introduction}

Quarries are important geoheritage sites with great potential for geoeducation (e.g. Petersen 2002) and geotourism (e.g. Pralong 2005; Stefano and Paolo 2017; Beranova et al. 2017; Baczyńska et al. 2018). It seems, however, that the work related to quarries primarily raises the scientific aspect of the geological heritage there. Clearly, less attention is devoted to their educational values. Simultaneously with a scientific value linked with geoheritage, quarries also have scenic, cultural, historic value related to how they are perceived by the public (Panizza 2001). Their potential for geoeducation and geotourism can be

This article is part of the Topical Collection on Geoheritage and Conservation: Modern Approaches and Applications Towards the 2030 Agenda, IX ProGEO Symposium, Poland, 25-28th June, 2018

Grzegorz Gajek

gajcy@umcs.pl

1 Faculty of Earth Sciences and Spatial Management, Maria Curie-Sklodowska University, Lublin, Poland evaluated by means of various assessment methods (Kubalíková 2013; Brilha 2016; Kasprowska-Nowak and Marek 2019). Quarries are a window into the past, making it possible to learn about our planet's environment of our planet of millions or thousands of years ago (Nita 2012; Beranova et al. 2017). In many areas, they are the only places where one can observe exposures of the bedrock that is usually covered by younger sediments, regolith or vegetation. Quarries enable the direct observation of rocks, minerals, geological structures and traces of various quarrying methods, and make possible the collection of rock samples and fossils (Babelewska et al. 2014). In addition to geoheritage values, quarries are often good viewing points and habitats of interesting vegetation (Baczyńska et al. 2018). The surveys conducted in the Lower Silesia Voivodship (SW Poland) indicate that approximately $50 \%$ of the inhabitants of areas where abandoned quarries occur visit them at least once a year. They form part of their living space, because they often spend time there (Baczyńska and Lorenc 2012). This indicates the huge educational potential of quarries.

The ability to observe rocks at their place of occurrence, often in extensive exposures, arouses interest and creates great 
educational opportunities. In Poland, there are many nonactive quarries, both as exceptional as for example Ślichowice (lying fold), Gacki (gipsum crystals), Gagaty Soltykowskie (dinosaur footprints) as well as hundreds sites with lower scientific but still high educational potential (Urban and Wróblewski 1999; Wróblewski 2000).

According to the first definition of geotourism proposed by Hose (1995), geoeducation is the most important part of this form of tourism: "The provision of interpretative and service facilities to enable tourists to acquire knowledge and understanding of the geology and geomorphology of a site." Therefore, the concept of geoeducation can be used in relation to both formal education (schools and universities) and informal education (geotourism).

The present-day school education in Poland offers a limited number of field classes. Hence, the possibility of direct observation of phenomena and processes and participation-based forms of learning taking advantage of access to natural sites gives a greater opportunity to achieve educational objectives than in the case of traditional forms of education. Field classes are important from the perspective of education, interpretation and promotion of geoheritage. Pupils and students prefer a teaching strategy offering participation-based forms of learning such as simulations and field trips (Fermeli et al. 2015). This type of teaching offers great opportunity to promote interest in geosciences and improve awareness of the importance of geoheritage (BerrocalCasero et al. 2018). Lessons in quarries provide an excellent opportunity for active learning — students can observe the occurrence of rocks and fossils in natural conditions, and not learn them on the basis of small debris. It is possible to check the characteristics of minerals and rocks, and collect your own specimens; it is also easier to implement a project task developing the ability to work in groups. All this increases the efficiency of learning. Furthermore, geoeducation products for schools can help build affection towards the surroundings and raise the awareness of the geoheritage value (Magagna et al. 2013). The basic problem faced by the teachers is, however, insufficient knowledge of the educational value of abiotic nature and the lack of adequate teaching materials. In addition, field lessons require a greater amount of work from the teacher.

The present study has had the following objectives: (i) evaluation of the geoeducational potential of the quarries located in the study area and of its spatial diversity, (ii) development of an assessment method that would allow the identification of sites suitable for various audience groups, and (iii) identification of advantages and disadvantages of the quarries as sites for geoeducation.

The geoeducational function of old quarries can constitute a form of their development, through the location of geological museums or educational centres within them. The examples of such sites are Devonian limestones quarries in Chęciny, Poland (Rzepka Quarry-European Centre For Geological Education, https://www.eceg.uw.edu.pl/en/), Kielce, Poland (Centre of Geoeducation, http://geopark- kielce.pl/centrum_geo/) or Brisighella, Italy (Stefano and Paolo 2017). In Poland, the most valuable sites are preserved as nature reserves - e.g. Wilcza Góra (Bobiński et al. 1999; Rogowski 2016), Gacki (Urban and Wróblewski 1999; Wróblewski 2000), Ślichowice (Urban and Wróblewski 1999). However, such reserves were created in the past to prevent the degradation of outstanding heritage. Basically, new forms of abiotic nature protection of such high rank are not being established any more nowadays.

The further development of abandoned quarries should take into account their potential educational function, and therefore, any action taken should not lead to a reduction in their value in this area (Sobala and Pukowiec 2014). Each object must be treated individually and all activities should take into account the local geoheritage values. It is also advisable to prepare a wider tourist offer taking into account, for example, the possibility of horse-riding, cycling or climbing tourism (Baczyńska et al. 2018). This may contribute to an increase in the number of people visiting quarries, who "by the way" will increase their knowledge of geology. Preparation for performing educational function requires detailed field inventory, resource analysis and preparation of appropriate products (interpretive boards, geo-trails, mobile apps). It is also necessary to secure the quarry and to prepare basic infrastructure (designation of the route and positions in the field and their marking). It is possible to conduct classes in quarries devoid of educational infrastructure, but this requires a good geological background of the teacher.

The occurrence of abiotic nature, landscape and cultural heritage within the Vistula River Gap between Zawichost and Puławy (Fig. 1) was the basis for preparing the project of the Małopolska Vistula River Gap Geopark that was commissioned by the Ministry of the Environment. It encompassed a detailed inventory of the area's geoheritage, as well as the identification and description of 225 geosites and more than 10 geotourist trails (Harasimiuk et al. 2011). The implementation of the Malopolska Vistula River Gap Geopark was acknowledged to be one of priorities of the Development strategy for the Lubelskie voivodship 2014 2020 (with a 2030 perspective) (http://www.strategia.lubelskie. pl/synteza/SYNTEZA_EN.pdf). Since it is the greatest concentration of Upper Cretaceous-Palaeocene exposures in eastern Poland, the geoeducational potential of this area is high. It could be tapped by establishing a Geopark that would offer an opportunity for the development of geotourism. Beyond doubt, geoparks are the most suitable areas for the development of the educational function (Zecha and Regelous 2018).

The convenient location of the study area close to Lublin and some smaller towns in the area enables teachers to organise short school trips and conduct geography field classes. At the same time, in Lublin, the largest of the cities mentioned above, there are schools of higher education with programs related to natural science 
Fig. 1 Location and geological map of the study area

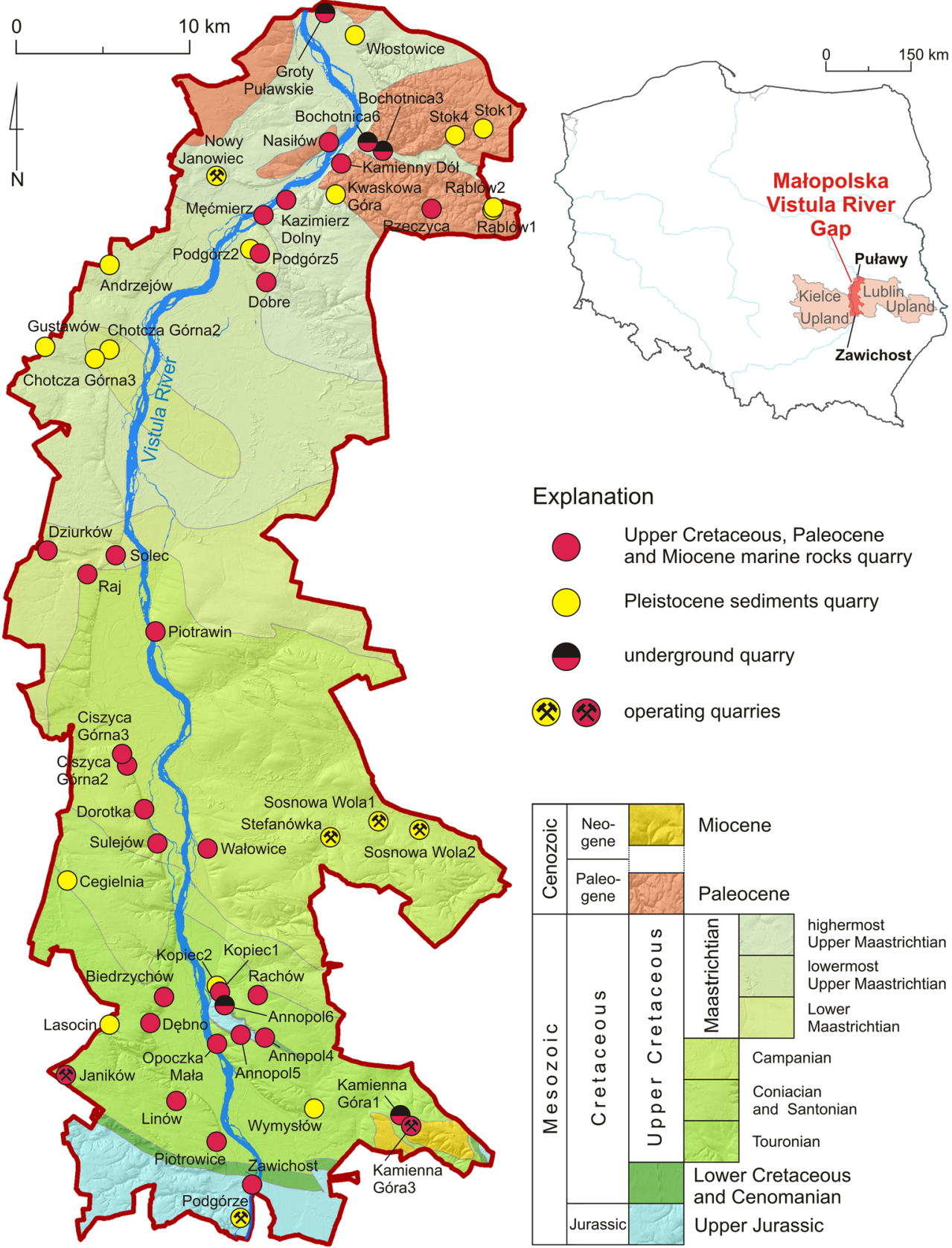

and the tourism industry. Given the educational value of the sites studied, it is possible to include field classes in the curricula. Moreover, many of the quarries are located in the Kazimierz Dolny area that is visited by large numbers of tourists each year. Even though they are attracted mainly by the cultural assets and scenic value of the town and its vicinity, this is an opportunity for enriching the existing "traditional" tourism by offering elements of geoeducation that are innovative in a sense. The potential audience of the educational offer can be divided into three groups: (i) primary and secondary school pupils, (ii) students of university-based natural science study programs, (iii) nonspecific tourists/geotourists.

\section{Geological Settings}

The evaluation was carried out in the area of the Małopolska Vistula River Gap (Kondracki 2000), located in SE Poland (Fig. 1). It covers approx. $1240 \mathrm{~km}^{2}$, and its axis is the Vistula valley. This forms an almost $85-\mathrm{km}$-long structural gap between the Kielce Upland in the west, and the Lublin Upland in the east. In the physical-geographic division of Poland, this stretch is part of the Lublin Upland.

Most of the study area lies in the eastern part of the marginal synclinorium referred to as the Puławy Basin (Pożaryski 1997; Narkiewicz and Dadlez 2008). A small south-western part of the study area, however, belongs to the Mesozoic 
margin of the Świętokrzyskie Mountains. The study area is built of Upper Cretaceous and Palaeocene carbonate and carbonate-siliceous rocks (mainly opoka and marl, limestone, gaize) dipping monoclinally (at 3 to $5^{\circ}$ ) to the NE. This system is disrupted in the central part of the study area by the anticline structure of the Chodel Basin (Harasimiuk 1980; Krzywiec and Wybraniec 2007). The southern part of the study area also features the small Annopol anticline, built of Upper Jurassic limestone and stratigraphically condensed Cretaceous siliceous-carbonate rocks dated to the Albian-Turonian Age (Walaszczyk 1992). Cretaceous rocks are overlain by a complex of Miocene carbonate rocks constituting a record of the environment of the tectonically active marginal zone of the sub-Carpathian depression (Oszczypko 1996; Wysocka et al. 2007) (Fig. 1). Above the bedrock lie bipartite Pleistocene sediments. The lower part of these sediments is made up of glacial (glacial tills) and fluvioglacial (sands and gravels) deposits. The upper part is made up of loess, up to $30 \mathrm{~m}$ thick, and aeolian sands in dunes, deposited during the Vistulian Glaciation (Harasimiuk and Henkiel 1978; Pożaryski et al. 1994; Marks et al. 2016).

The Vistula valley, incised into relatively resistant Cretaceous rocks to the depth reaching $30 \mathrm{~m}$, has the character of a structural gap. Besides landforms related to fluvial activity, landform characteristic of post-glacial uplands, loess plateaus and sand dunes occur on both sides of the valley. In addition, there are a few large landforms which result from active tectonics and tectonic pre-design of relief, including some sections of the topographic margins of the Vistula valley, the southern escarpment of the Lublin Upland and the cuesta escarpments on tilted sedimentary strata.

The quarries in the northern stretch of the Vistula River Gap contain a lithological record of marine regression during the Mesozoic/Cenozoic transition, as well as traces of the Yucatan impact related to one of the landmark events in the history of the Earth, i.e. the great extinction of organisms at the K-Pg boundary (Pożaryska and Pożaryski 1951; Machalski 1998, 2005a, b). Furthermore, the Upper Cretaceous opoka is famous for its spectacular invertebrate fossils, corresponding to the conditions of the progressing marine regression, as well as vertebrate and flora fossils (Abdel-Gawad 1986; Słodkowska 2003; Żarski et al. 1998). These exposures are thus attractive for fossil collectors, and Polish legislation allows collecting minerals, rocks and fossils for scientific, collector and didactic purposes but without performing mining works (Ustawa z dnia 9 czerwca 2011 r. - Prawo geologiczne i górnicze). Aside from assets related to Cretaceous geology, it is possible to include various topics such as the use of rock material in architecture, as well as the historical and presentday exploitation of rocks.

Loess-palaeosol sequences are interesting geological formations constituting an archive of the Earth's climate history over many glacial and interglacial cycles, or even geological ages (e.g. Kukla 1977; Pecsi 1990) and are used for geotourism (Vasiljević et al. 2011; Solarska et al. 2013). In the Małopolska Vistula River Gap, the loess cover, up to $30 \mathrm{~m}$ thick, represents an important element of geodiversity (Harasimiuk and Henkiel 1978), and there are important loess sections for understanding climatic and environmental change in this region during the Pleistocene (Maruszczak 1991, 1995, 2000; Dolecki et al. 2004). The gully network, unique on the European scale, offers an opportunity to discuss topics related to geohazards, particularly past and present soil erosion, climate changes and human impact on landscape (Zgłobicki et al. 2015, 2019).

The study area is characterised by many centuries of quarrying of local rock materials (Table 1), mainly CretaceousPaleogene rocks, starting from the exploitation of Świeciechów flint in the Palaeolithic period (between Kopiec2 and Wałowice geosites) (Fig. 1). The development of quarrying is closely linked with the historic (seventeenthnineteenth century) exploitation of rock materials for the needs of local construction, e.g. chamber quarries in Bochotnica and the so-called Groty Puławskie (Puławy Grottos) (Fig. 1) (Pinińska 2007). For a few decades in the first half of the twentieth century, phosphorite was mined in Annopol. The abandoned mine, with tens of kilometres of galleries and dip-headings, deserves protection and preservation for future generations (Machalski and Liwiński 2018). At the same time, raw materials were obtained for the cement industry and for river engineering on the Vistula (Piotrawin, Nasiłów, Kazimierz Dolny). Quarries vary in terms of size: small ones predominate (up to $100 \mathrm{~m}$ long and $10 \mathrm{~m}$ high) and often expose intact rocks. While the area of most quarries is not properly secured or maintained, large exposures, up to $500 \mathrm{~m}$ or more in length and $30 \mathrm{~m}$ in height (Piotrawin, Nasiłów, Kazimierz Dolny, Opoczka Mała), underwent some rehabilitation in the late twentieth century and are quite safe now. Several hundred meters long old mining galleries and chambers in the northern part of the area of interest (Groty Puławskie, Bochotnica), have undergone preservation, are almost intact and can be made open to the public.

\section{Method}

The undertaken comprehensive assessment encompasses categories of values significant from the perspective of formal education (pupils and students) and informal education (tourists). These include scientific, functional and tourist values. Educational and scientific values were recognised as main values, with functional and tourist values as secondary. A total of 20 criteria commonly used in such studies were implemented (see e.g. Reynard et al. 2007, 2016; Vujičić et al. 2011; Kubalíková 2013; Neches 2013; Kubalíková and Kirchner 
Table 1 The biggest and best documented quarries of the Małopolska Vistula River Gap

\begin{tabular}{|c|c|c|c|c|c|}
\hline & \multirow[t]{2}{*}{ Basic information } & \multicolumn{3}{|l|}{ Stratigraphy } & \multirow[t]{2}{*}{ Lithology } \\
\hline & & System & Series & Stage & \\
\hline Annopol & $\begin{array}{l}\text { The phosphorite mine established in 1952; in } \\
1971 \text { the mining of phosphorites was } \\
\text { discontinued due to its unprofitability; } \\
\text { numerous marine fauna fossils; more than } \\
110 \text { km galleries used in the heyday of the } \\
\text { mine (i.a. Machalski et al. 2009; Machalski } \\
\text { and Kennedy 2013; Komorowski et al. 2016; } \\
\text { Lorenc et al. 2016) }\end{array}$ & Cretaceous & $\begin{array}{l}\text { Upper Cretaceous } \\
\text { Lower Cretaceous }\end{array}$ & $\begin{array}{l}\text { Turonian } \\
\text { Cenomanian } \\
\text { Albian }\end{array}$ & Phosphorite; limestones; marls \\
\hline Bochotnica6 & $\begin{array}{l}\text { Abandoned chamber quarries; the beginning of } \\
\text { exploitation dated to the fourteenth century; } \\
\text { geological site "Ścianka Pożaryskich"; } \\
\text { designated to be part of the European } \\
\text { Network of Geosites (i.a. Hansen et al. 1989; } \\
\text { Machalski 2005a, b, 2007; Machalski and } \\
\text { Jagt 2018; Alexandrowicz 2006) }\end{array}$ & $\begin{array}{l}\text { Paleogene } \\
\text { Cretaceous }\end{array}$ & $\begin{array}{l}\text { Palaeocene } \\
\text { Upper Cretaceous }\end{array}$ & $\begin{array}{l}\text { Danian } \\
\text { Maastrichtian }\end{array}$ & Ppokas; gaizes; limestones \\
\hline Janików & $\begin{array}{l}\text { Bryozoan limestones quarries; the beginning of } \\
\text { exploitation dated to the sixteenth century } \\
\text { designated to be part of the European } \\
\text { Network of Geosites (i.a. Walaszczyk 1992; } \\
\text { Walaszczyk et al. 1999; Alexandrowicz } \\
\text { 2006) }\end{array}$ & Cretaceous & Upper Cretaceous & Turonian & limestones \\
\hline Kamienny Dół & $\begin{array}{l}\text { Abandoned quarry; site of finding the skeleton } \\
\text { remains, first in Poland and fourth in Europe, } \\
\text { of Early Palaeocene crocodile of the genus } \\
\text { Thoracosaurus leidy, } 1852 \text { (i.a. Machalski } \\
\text { 1998; Machalski and Jagt 2018; Żarski et al. } \\
\text { 1998) }\end{array}$ & $\begin{array}{l}\text { Paleogene } \\
\text { Cretaceous }\end{array}$ & $\begin{array}{l}\text { Palaeocene } \\
\text { Upper Cretaceous }\end{array}$ & $\begin{array}{l}\text { Danian } \\
\text { Maastrichtian }\end{array}$ & Opokas; gaizes; limestones \\
\hline Kazimierz Dolny & $\begin{array}{l}\text { Abandoned municipal quarry; numerous marine } \\
\text { fauna fossils; designated to be part of the } \\
\text { European Network of Geosites (i.a. } \\
\text { Pożaryska 1952; Abdel-Gawad 1986; } \\
\text { Machalski 2005a, b; Świerczewska-Gładysz } \\
\text { 2006; Alexandrowicz 2006) }\end{array}$ & Cretaceous & Upper Cretaceous & Maastrichtian & Opokas \\
\hline Nasiłów & $\begin{array}{l}\text { Abandoned quarry with the K-Pg boundary; } \\
\text { numerous marine fauna fossils; designated to } \\
\text { be part of the European Network of Geosites } \\
\text { (i.a. Walaszczyk et al. 1999; Alexandrowicz } \\
\text { 2006; Świerczewska-Gładysz and } \\
\text { Olszewska-Nejbert 2006) }\end{array}$ & $\begin{array}{l}\text { Paleogene } \\
\text { Cretaceous }\end{array}$ & $\begin{array}{l}\text { Palaeocene } \\
\text { Upper Cretaceous }\end{array}$ & $\begin{array}{l}\text { Danian } \\
\text { Maastrichtian }\end{array}$ & Opokas; gaizes; limestones \\
\hline Opoczka Mała & $\begin{array}{l}\text { Abandoned quarry for opoka with chert or flint; } \\
\text { place of finding the largest ammonite in } \\
\text { Poland - Lewesiceras peramplum; designated } \\
\text { to be part of the European Network of } \\
\text { Geosites (i.a. Walaszczyk 1992, 2004; } \\
\text { Walaszczyk et al. 1999; Alexandrowicz 2006; } \\
\text { Kin and Niedźwiedzki 2012) }\end{array}$ & Cretaceous & Upper Cretaceous & Turonian & Opokas \\
\hline Piotrawin & $\begin{array}{l}\text { The biggest abandoned quarry in the Vistula } \\
\text { River Gap; numerous marine fauna fossils; } \\
\text { designated to be part of the European } \\
\text { Network of Geosites (i.a. Walaszczyk 2004; } \\
\text { Alexandrowicz 2006; Machalski 2012) }\end{array}$ & Cretaceous & Upper Cretaceous & Campanian & Opokas; marls \\
\hline
\end{tabular}

2016; Brilha 2016), and the selection and scoring rules were prepared by the authors of the present study (Table 2).

In the course of the work, the authors carried out a synthetic assessment of the values of the quarries, as well as three assessments for the particular audience groups, with different weightings assigned to the specific categories of values (Table 3). The results of the overall assessments were multiplied by the proposed coefficients. Such an approach is usually employed in such studies, and assumes that not all values are equally significant from the perspective of different 


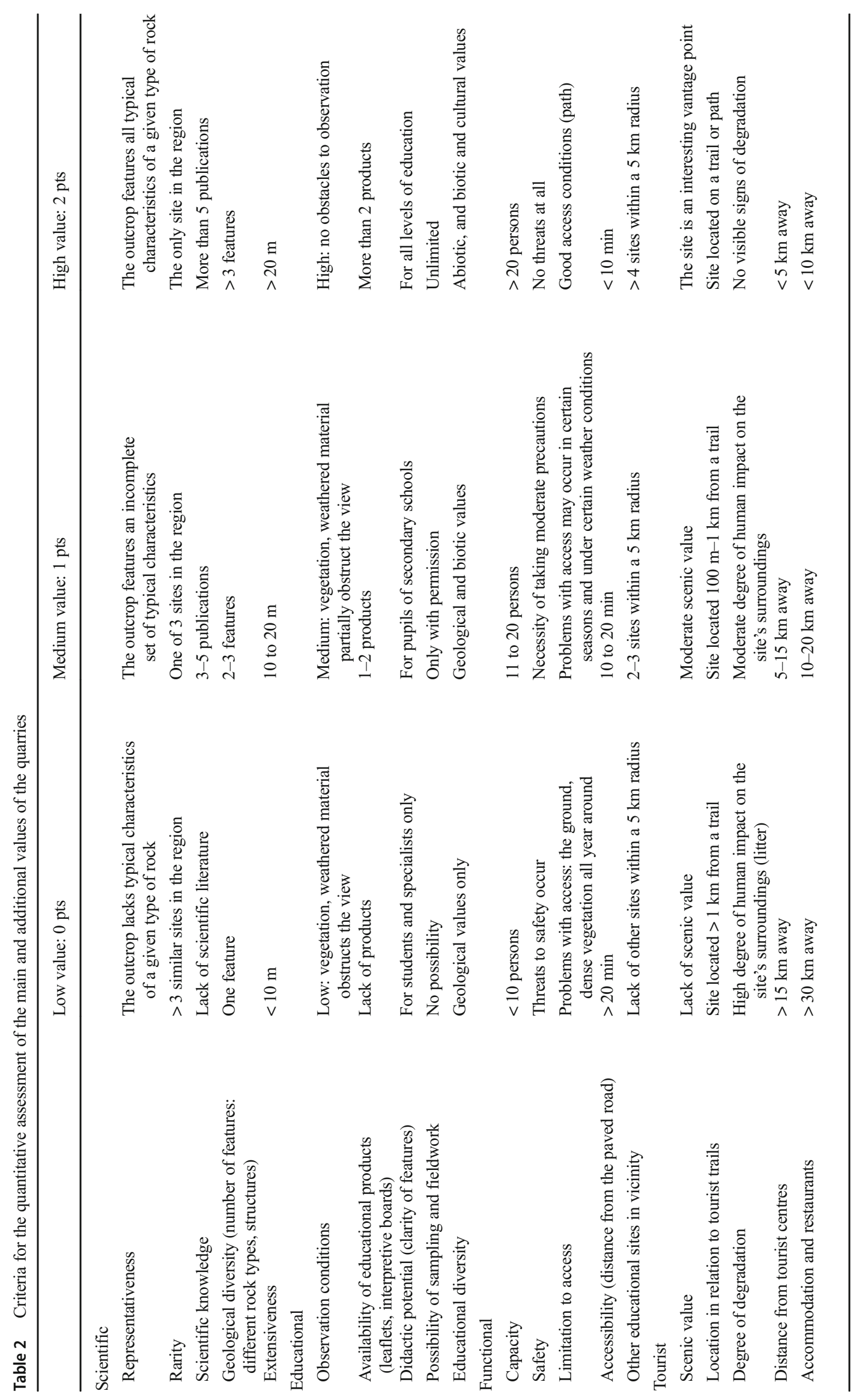


Table 3 Weightings of categories of values for different audiences

\begin{tabular}{lllll}
\hline & Scientific & Educational & Functional & Tourist \\
\hline University students & 2.0 & 1.5 & 1.0 & 1.0 \\
School pupils & 1.0 & 2.0 & 1.5 & 1.0 \\
Tourists & 1.0 & 1.0 & 1.5 & 2.0 \\
\hline
\end{tabular}

audience groups (Pralong 2005; Feuillet and Sourp 2011; Brilha 2016; Różycka and Migoń 2018). As the maximum value for each group was $10 \mathrm{pts}$, the maximum synthetic score (without weighting) that could be awarded to a quarry was 40 pts. In each case (synthetic assessment, assessment in the particular category of values, results obtained for different audience groups), the final score obtained by the quarries was divided into five class intervals. For class intervals, the Equal Interval method used by ArcMap 10.6.1 software was employed. The following value classes were distinguished: (1) very low, (2) low, (3) medium, (4) high, (5) very high (Table 4). A detailed analysis was subsequently carried out for 53 quarries where rock material was or still is quarried ( 7 quarries). Out of these 53 , there are 33 quarries where carbonate and siliciclastic-carbonate rocks used to be quarried. In the remaining 20 quarries, Pleistocene sediments (sands, gravels, tills, loess) were mined.

In the study, we use the approach proposed by Vujičić et al. (2011). Four categories were merged into two: (i) main values (scientific + educational) and (ii) additional values (tourist + functional). This enabled a two-dimensional analysis and synthetic assessment of the values of the quarries (Fig. 5).

\section{Results}

The analysed quarries are distributed unevenly and are concentrated in two groups: in the northern and southern part of the study area (Fig. 1). The northern part includes 22 inventoried quarries, of which 12 sites are of Pleistocene sediments (mainly loess, sands, tills) and 10 sites are of Upper Cretaceous-Palaeocene rocks, mainly opokas, marls, gaizes and limestones. A slightly smaller concentration of 18 quarries is located in the southern part of the study area. These quarries are characterised by the greatest diversity of types, origins and age of rocks. Here, the oldest rocks represent deep-sea carbonate rocks of the lowermost Upper Cretaceous series (opokas, marls, limestones). Shallow-water (reef) Miocene (Neogene) limestone and Pleistocene (Quaternary) sand-gravel sediments can be found here. The quarries in the central part of the studied area (13 quarries), of opokas and marls of the middle stages of the Upper Cretaceous (Campanian and Lower Maastrichtian), are located within the rocky walls of the Vistula River Gap (e.g. Piotrawin, Sulejów, Dziurków), or in the local deposits of Pleistocene detrital rocks (e.g. Cegielnia, Stefanówka) (Fig. 1).

Fourteen quarries (26\% of all 53 quarries in the study area) are characterised by very high or high scientific value, while nearly $38 \%$ of the sites under study are of low or very low scientific value (Fig. 2a). Nine quarries with high or very high value feature outcrops of rocks originating from the Upper Cretaceous and the Upper Cretaceous-Palaeocene transition, and four of these were designated to be part of the European Network of Geosites: the municipal quarry in Kazimierz Dolny, the quarry in Opoczka Mała, that in Piotrawin, as well as the quarry in Bochotnica (documentation site Ścianka Pożaryskich) (Alexandrowicz 2006). Two of the highest-rated quarries (Kamienna Góra1, Kamienna Góra3) in the scientific category feature Miocene sediment exposures, and three quarries feature Pleistocene sediments (Cegielnia. Rąblów2, Nowy Janowiec).

Very high and high educational value was determined for 14 quarries, among which nine also received a high score for their scientific value (Fig. 2a). More than half (28, i.e. $53 \%$ ) of the quarries have low educational value (Fig. 2b). Most of the quarries under study (34, i.e. 64\%) have high functional value; nine (17\%), however, have low and very low functional value (Fig. 3a). In terms of tourist value, nearly half of the quarries (23, i.e. $43 \%$ ) received a high score, while 18 (i.e. one third) had a low score (Fig. 3b).

Table 4 Ranking classes intervals for different categories of values and audience related assessments

\begin{tabular}{|c|c|c|c|c|c|c|c|c|}
\hline \multirow[t]{2}{*}{ Class } & \multicolumn{4}{|c|}{ Categories of values } & \multirow[t]{2}{*}{ Total value } & \multicolumn{3}{|c|}{ Audience-related assessments ${ }^{1}$} \\
\hline & Scientific & Educational & Functional & Touristic & & School pupils & University students & Tourists \\
\hline Very low & $2.00-3.40$ & $1.00-2.80$ & $3.00-4.20$ & $0.00-1.80$ & $12.00-16.40$ & $16.50-21.90$ & $15.50-21.90$ & $16.00-22.00$ \\
\hline Low & $3.41-4.80$ & $2.81-4.60$ & $4.21-5.40$ & $1.81-3.60$ & $16.41-20.80$ & $21.91-27.30$ & $21.91-28.30$ & $22.01-28.00$ \\
\hline Medium & $4.81-6.20$ & $4.61-6.40$ & $5.41-6.60$ & $3.61-5.40$ & $20.81-25.20$ & $27.31-32.70$ & $28.31-34.70$ & $28.01-34.00$ \\
\hline High & $6.21-7.60$ & $6.41-8.20$ & $6.61-7.80$ & $5.41-7.20$ & $25.21-29.60$ & $32.71-38.10$ & $34.71-41.10$ & $34.00-40.00$ \\
\hline Very high & $7.61-9.00$ & $8.21-10.00$ & $7.81-9.00$ & $7.21-9.00$ & $29.61-34.00$ & $38.11-43.50$ & $41.11-47.50$ & $40.01-46.00$ \\
\hline
\end{tabular}

${ }^{1}$ Including coefficients from Table 3 
Fig. 2 Scientific (a) and educational (b) values of the quarries a SCIENTIFIC VALUE

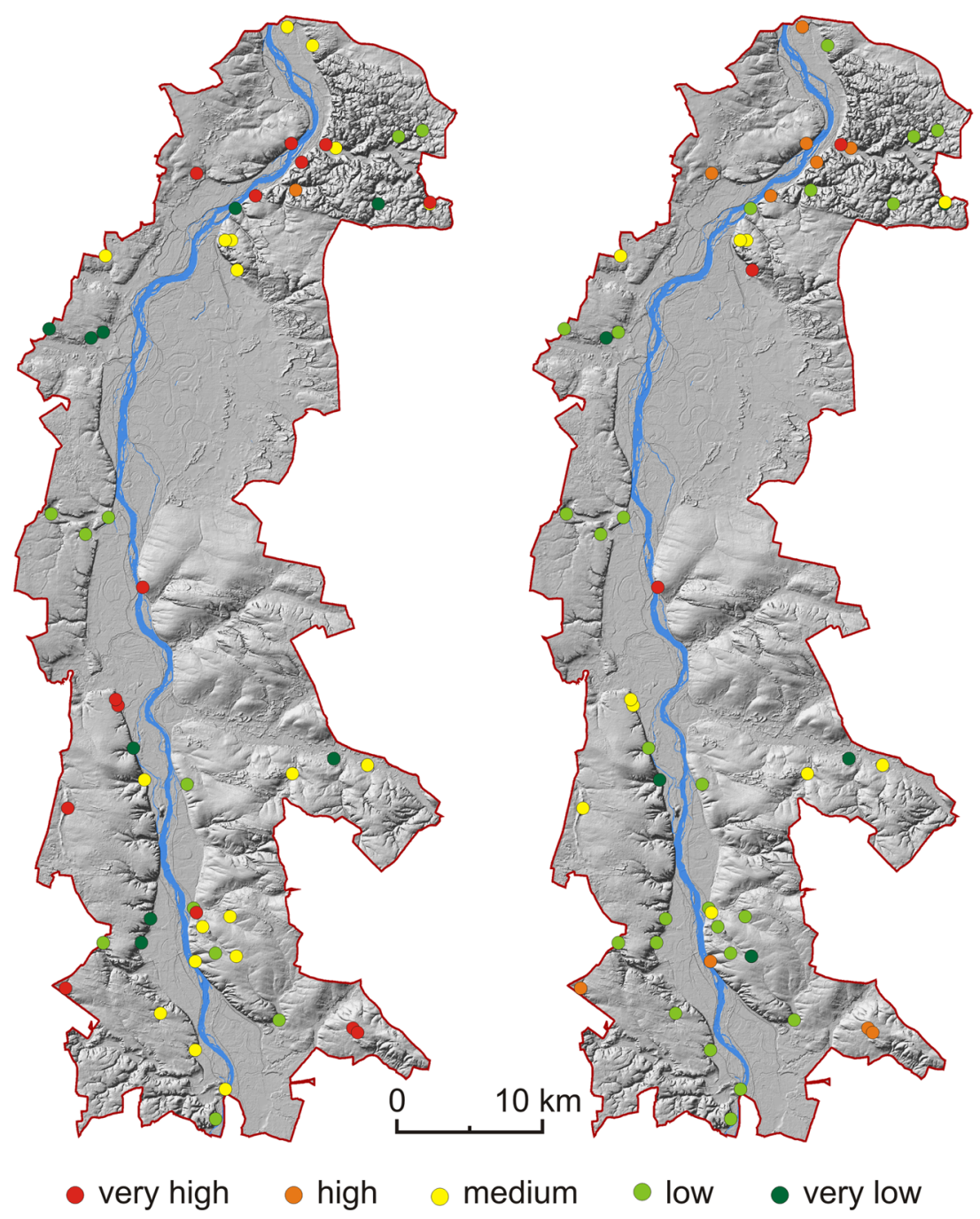

The final scores for the specific groups result from the assessment of the particular criteria. Below is a list of criteria with the highest and lowest scores for all quarries. The following criteria received the highest mean score: (1) capacity of the site (functional value)-1.75 pts; (2) possibility of sampling (educational value)-1.74 pts; (3) accessibility (functional value) and representativeness (scientific value)-1.58 pts; (4) limitation to access (functional value)- $1.50 \mathrm{pts}$; (5) extensiveness (scientific value) - $1.50 \mathrm{pts}$. In turn, the following criteria received the lowest score: (1) accessibility of educational products (educational value) $-0.3 \mathrm{pts}$; (2) rarity (scientific value) -0.64 pts; (3) availability of literature (scientific value) and scenic value (tourist value) $-0.68 \mathrm{pts}$; (4) location in relation to tourist trails (tourist value) $-0.81 \mathrm{pts}$; (5) degree of degradation (tourist value) $-0.86 \mathrm{pts}$.

The relationship between the groups of values was measured upon the evaluation results for the specific categories. The results show that a statistically greatest correlation exists between scientific and educational values (Pearson's correlation coefficients $r=0.64$ ). There is no statistically significant correlation between groups of scientific and functional values $(r=-0.01)$, educational and functional values $(r=0.13)$ and scientific and tourist values $(r=0.18)$. Finally, a poor correlation occurs between educational and tourist values $(r=0.29)$ (Table 5).

The synthetic assessment shows that nearly 28 (53\%) quarries have considerable total value (very high, high and medium) and, consequently, a potential for being used in geoeducation (Fig. 4). Eight of the quarries (15\%) are quarries with very high total value (Bochotnica, Piotrawin, Kamienny Dół, Kazimierz Dolny, Nasiłów, Opoczka Mała, Rąblów, Dobre) (Table 6, Fig. 4). Twenty-five quarries (47\%) have low and very low total value (e.g. Gustawów, Wałowice, Piotrowice, Sulejów, Dorotka). The quarries in Bochotnica and Piotrawin (Fig. 5a, b) were given the highest total scores (34 pts). 
Fig. 3 Functional (a) and tourist (b) values of the quarries a FUNCTIONAL VALUE

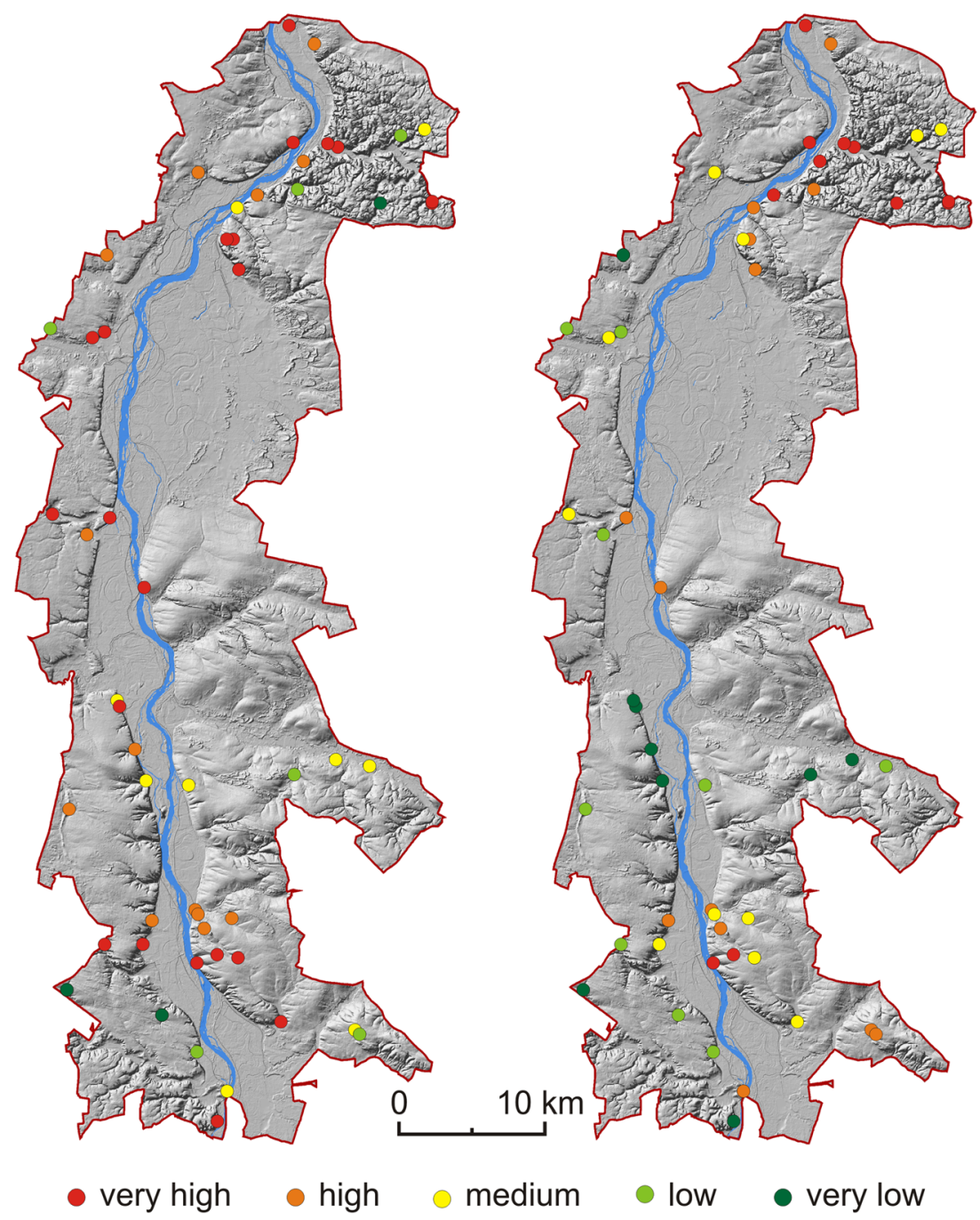

The results of the evaluation of quarries regarding the geoeducational needs of the three audience groups show that 16 quarries $(30 \%)$ have a high educational usefulness for university students and geotourists, while 14 quarries (26\%) show usefulness for pupils and students (Fig. 6). Most of the quarries are outcrops of rocks representing the marine environments of the Upper Cretaceous and Palaeocene, as well as the Miocene. Eleven quarries are of high value for each of the three audience groups. Statistical Pearson's correlation between the assessment results for various audience groups was found to be strong (Table 7).

Results of two-dimensional analysis and synthetic assessment proposed by Vujičić et al. (2011) indicated that quarries with moderate main and additional values predominate. Twelve sites (23\%) are quarries where the highest (very high and high) scientific and educational values are accompanied by the highest (very high and high) functional and tourist
Table 5 Statistical correlation between categories of values (the numbers are Pearson's correlation coefficients)

\begin{tabular}{lllll}
\hline & Scientific value & Educational value & Functional value & Touristic value \\
\hline Scientific value & 1.00 & - & - & - \\
Educational value & 0.64 & 1.00 & - & - \\
Functional value & -0.01 & 0.13 & 1.00 & - \\
Touristic value & 0.18 & 0.29 & 0.35 & 1.00 \\
\hline
\end{tabular}




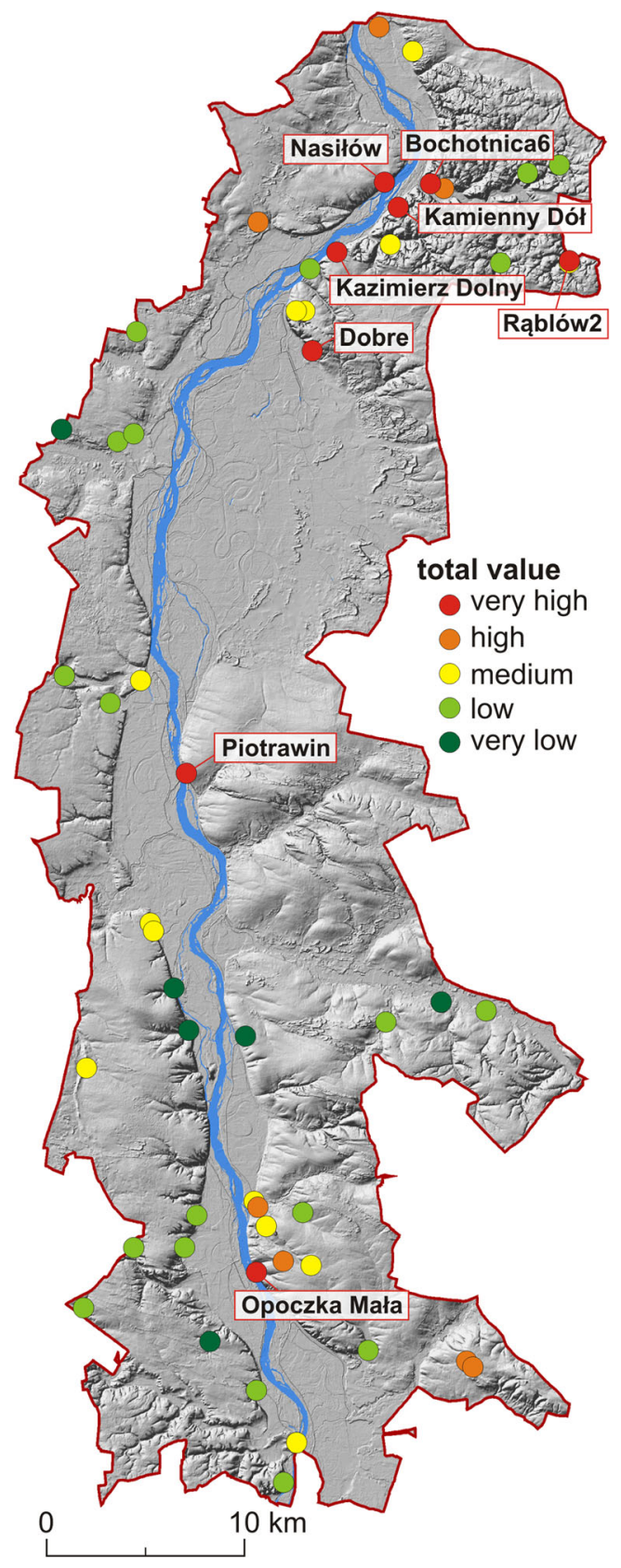

Fig. 4 Synthetic assessment of geotourist value (total value)

values (Fig. 7). Nearly all of these are quarries where, historically, Upper Cretaceous opokas and marls were quarried and where Palaeocene gaizes with limestones inserts are exposed. One of these (Rablów2) features Pleistocene fluvioglacial sediments. Most of these quarries are located in the northern part of the study area. In three quarries, very high and high main values are not accompanied by high additional values (Ciszyca Górna3, Janików, Stefanówka) (Fig. 1). It should be noted, however, that another four quarries (Kamienna Góra3, Cegielnia, Ciszyca Górna2, Sosnowa Wola) (Fig. 1) are characterised by high main values and only moderate additional values.

\section{Discussion}

The investigation shows that twelve quarries are sites that have both highest scientific and educational values and highest functional and tourist values (Bochotnica6, Piotrawin, Kamienny Dół, Kazimierz Dolny, Nasiłów, Dobre, Nowy Janowiec, Rąblów2, Opoczka Mała, Kamienna Góra1, Kopiec, Bochotnica3) (Fig. 7). This group of quarries offers the best prospects for use in geoeducation. At the same time, six of these (Bochotnica6, Piotrawin, Kamienny Dół, Kazimierz Dolny, Nasiłów, Opoczka Mała) have already been designated to be part of the European Network of Geosites (Alexandrowicz 2006) due to their high scientific value. Most of the quarries with prospects for geoeducation feature fossil-rich, lithologically varied carbonate rocks formed in the seas of the Late Cretaceous and Palaeocene; there are also quarries of Pleistocene fluvioglacial and glacigenic sediments (e.g. Cegielnia, Rąblów1). The quarries with the highest scientific, educational and functional value usually have a high value with regard to both formal (pupils and university students) and informal education (tourists) (Fig. 6). Despite using various weights of criteria associated with the three distinguished audience groups, strong relationship occur between the assessment results of the particular quarries (e.g. Bochotnica6, Rąblów2, Piotrawin). This indicates that geoeducation for tourists, pupils and university students can be conducted in most of the quarries. Of note, Różycka and Migoń (2018) reached similar conclusions when studying the geoheritage of the Kaczawskie Foothills and Mountains.

The evaluated quarries received high scores in the key categories (site capacity, possibility of sampling) from the perspective of their use for education purposes. This offers good prospects for their extensive use in geoeducation. In the case of three quarries (Ciszyca Górna3, Stefanówka, Janików), however, despite their high scientific and educational value, their use for geoeducation will be quite difficult due to their low functional value - low safety and accessibility and lack of other educational sites in vicinity (Fig. 7). Taking measures in this respect would require high financial expenditure and could encompass only some of the functional values. In the other eight quarries, measures need to be taken to improve additional (functional and tourist) values (that are currently assessed as medium). Similar conclusions can be drawn from the analysis of the statistical correlation between the groups of values of all quarries, according to which the high scientific value of quarries has a strong influence on their educational value (Table 7). However, the lack of correlation or poor correlation between scientific value and other groups of values indicates that scientifically attractive quarries are not accompanied by geoeducational products (leaflets, interpretive boards, trails) and they are often located far from the existing infrastructure (functional value). The situation is similar in the 
Table 6 The highest rated quarries within the Małopolska Vistula River Gap study area

\begin{tabular}{|c|c|c|c|c|c|c|c|c|c|}
\hline \multirow{2}{*}{$\begin{array}{l}\text { Name of } \\
\text { the site }\end{array}$} & \multirow{2}{*}{$\begin{array}{l}\text { Location } \\
\text { (coordinates) }\end{array}$} & \multicolumn{5}{|c|}{ Geotouristic values } & \multicolumn{3}{|c|}{ Group of audiences } \\
\hline & & $\begin{array}{l}\text { Total } \\
(\max 40 \mathrm{pts})\end{array}$ & $\begin{array}{l}\text { Scientific } \\
(\max 10 \mathrm{pts})\end{array}$ & $\begin{array}{l}\text { Educational } \\
\text { (max } 10 \text { pts) }\end{array}$ & $\begin{array}{l}\text { Functional } \\
\text { (max } 10 \text { pts) }\end{array}$ & $\begin{array}{l}\text { Touristic } \\
\text { (max } 10 \mathrm{pts})\end{array}$ & $\begin{array}{l}\text { School } \\
\text { pupils }\end{array}$ & $\begin{array}{l}\text { University } \\
\text { students }\end{array}$ & Tourists \\
\hline Bochotnica & $\begin{array}{l}51^{\circ} 20^{\prime} 33.08^{\prime \prime} \mathrm{N} \\
21^{\circ} 59^{\prime} 36.63^{\prime \prime} \mathrm{E}\end{array}$ & 34 & 9 & 9 & 8 & 8 & 42.5 & 47.5 & 46 \\
\hline Piotrawin & $\begin{array}{l}51^{\circ} 05^{\prime} 27.90^{\prime \prime} \mathrm{N} \\
21^{\circ} 48^{\prime} 11.70^{\prime \prime} \mathrm{E}\end{array}$ & 34 & 8 & 10 & 9 & 7 & 43.5 & 47 & 45.5 \\
\hline Kamienny Dół & $\begin{array}{l}51^{\circ} 19^{\prime} 59.33^{\prime \prime} \mathrm{N} \\
21^{\circ} 58^{\prime} 08.29^{\prime \prime} \mathrm{E}\end{array}$ & 32 & 9 & 8 & 7 & 8 & 39.5 & 45 & 43.5 \\
\hline $\begin{array}{l}\text { Kazimierz } \\
\text { Dolny }\end{array}$ & $\begin{array}{l}51^{\circ} 18^{\prime} 54.18^{\prime \prime} \mathrm{N} \\
21^{\circ} 55^{\prime} 23.17^{\prime \prime} \mathrm{E}\end{array}$ & 32 & 8 & 8 & 7 & 9 & 39.5 & 44 & 44.5 \\
\hline Nasiłów & $\begin{array}{l}51^{\circ} 20^{\prime} 38.90^{\prime \prime} \mathrm{N} \\
21^{\circ} 57^{\prime} 43.00^{\prime \prime} \mathrm{E}\end{array}$ & 31 & 8 & 7 & 8 & 8 & 38.5 & 42.5 & 43 \\
\hline Opoczka Mała & $\begin{array}{l}50^{\circ} 52^{\prime} 47.80^{\prime \prime} \mathrm{N} \\
21^{\circ} 50^{\prime} 16.70^{\prime \prime} \mathrm{E}\end{array}$ & 31 & 6 & 8 & 9 & 8 & 39.5 & 41 & 43.5 \\
\hline Rąblów & $\begin{array}{l}51^{\circ} 18^{\prime} 26.04^{\prime \prime} \mathrm{N} \\
22^{\circ} 05^{\prime} 30.05^{\prime \prime} \mathrm{E}\end{array}$ & 31 & 9 & 5 & 8 & 9 & 37.5 & 42.5 & 44 \\
\hline Dobre & $\begin{array}{l}51^{\circ} 16^{\prime} 23.37^{\prime \prime} \mathrm{N} \\
21^{\circ} 54^{\prime} 12.57^{\prime \prime} \mathrm{E}\end{array}$ & 30 & 6 & 9 & 9 & 6 & 39 & 40.5 & 40.5 \\
\hline
\end{tabular}

case of the geotourism potential of loess landforms in the area of interest (Warowna et al. 2016). Among quarries located in other parts of Poland, there are quarries with high geoeducational and geotourism value, as well as sites where high scientific value is accompanied by low functional and tourist value (Dmytrowski and Kicińska 2011; Różycka and Migoń 2018).

The possibilities for the development of geotourism and geoeducation in the quarries are shown by the SWOT analysis in Table 8. The analysis indicates that with an increased interest
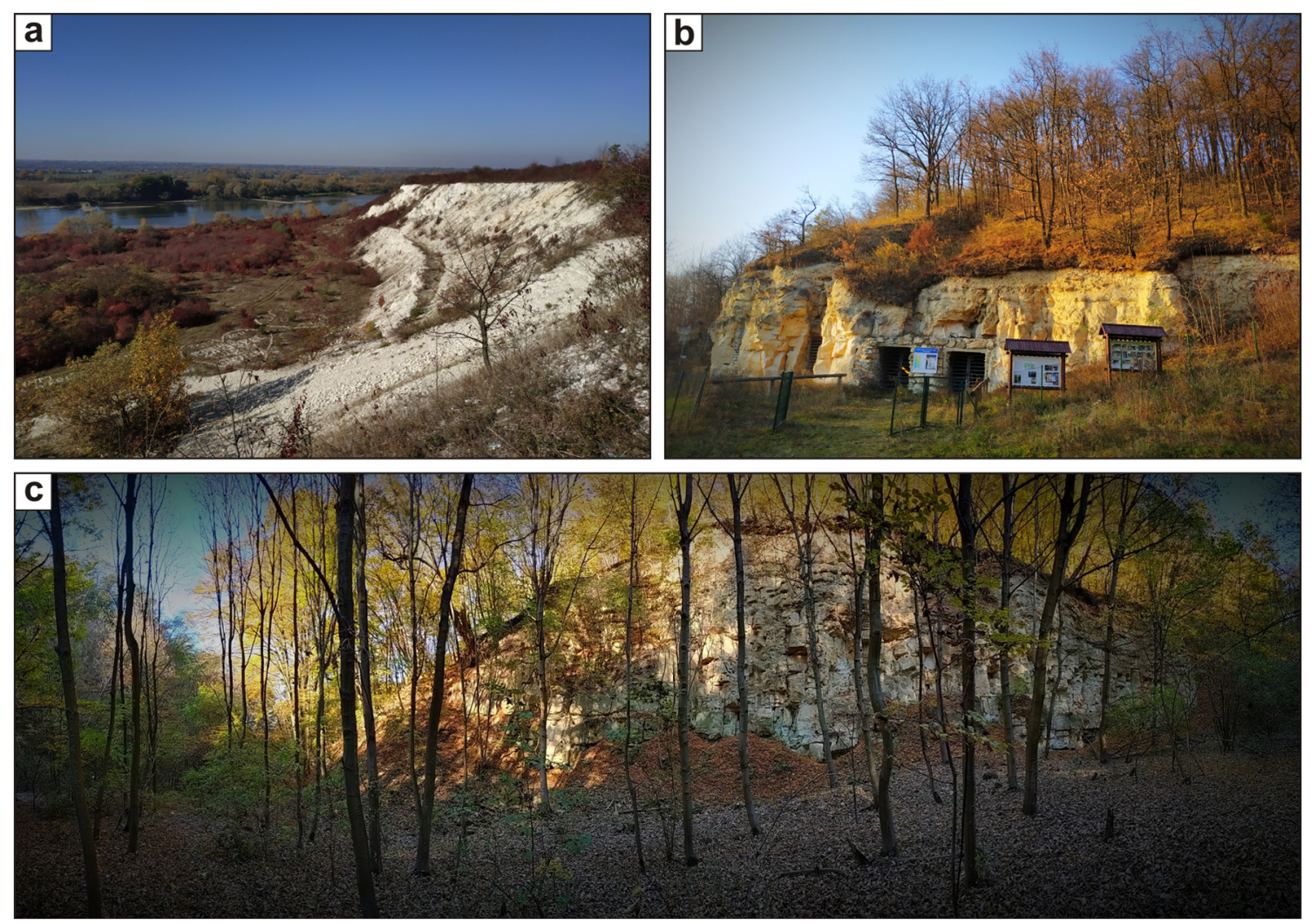

Fig. 5 Quarries with the highest total (=geotourists) values. a Piotrawin — the biggest abandoned quarry in the Vistula Gap. b Abandoned chamber (underground) quarries in Bochotnica. c Kamienny Dół—abandoned opoka quarry (all photographs by G. Gajek) 
a PUPILS

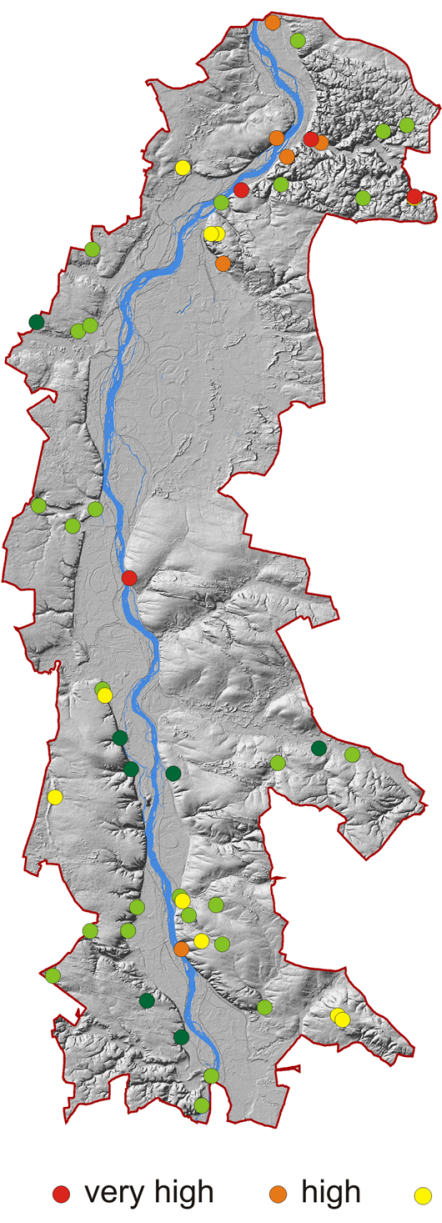

$\mathrm{b}$ STUDENTS

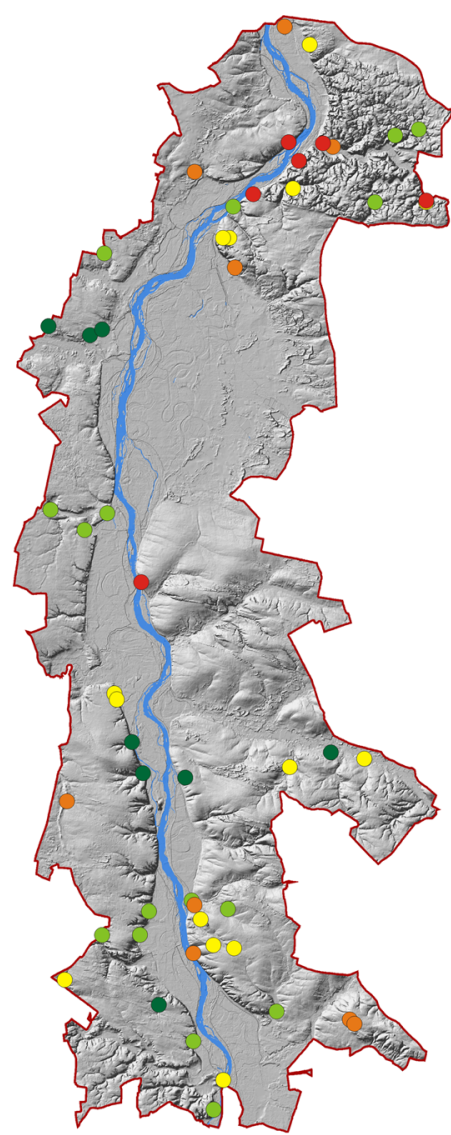

C TOURISTS

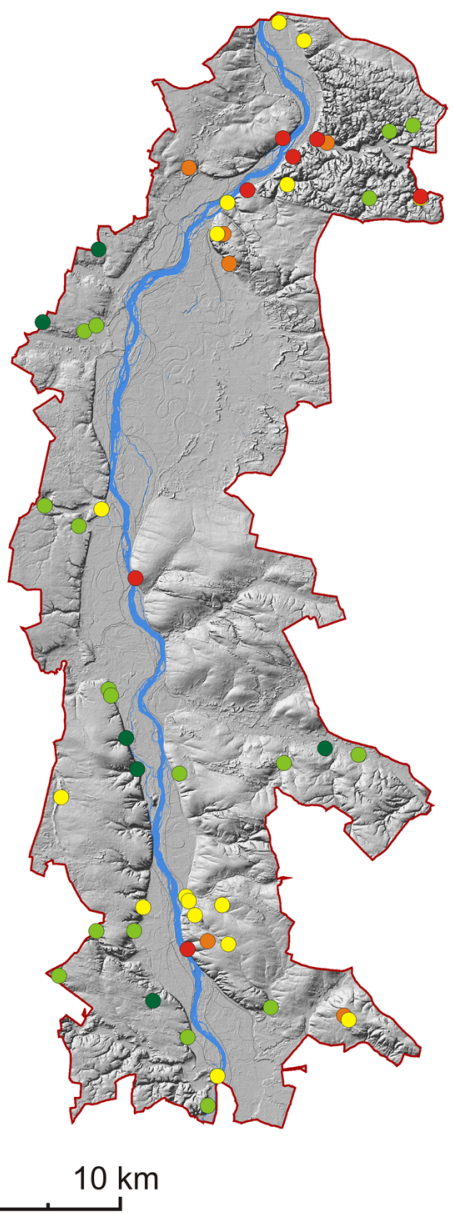

Fig. 6 Geoeducational value of the quarries for different audience groups. a School pupils. b University students. c Tourists

in active and cognitive tourism and a greater participation of external factors (local action groups, local government bodies, trained staff), there is an opportunity for a quick development of geotourism in the area. Besides the preparation of geoeducational and geotourism products, it is important to include quarries as a tour offer at the travel agencies. This would require the proper training of guides - as their current knowledge of the geoheritage of the study area is very poor. Another challenge for the study area is the lack of appropriately prepared online geoheritage information. Furthermore, it should also be stressed that in some quarries, processes reducing their

Table 7 Statistical correlation between results of assessment of various audience groups (the numbers are Pearson's correlation coefficients)

Total School pupils University students Tourists

\begin{tabular}{lllll}
\hline Total & 1.00 & - & - & - \\
School students & 0.99 & 1.00 & - & - \\
University students & 0.98 & 0.97 & 1.00 & - \\
Tourists & 0.97 & 0.96 & 0.90 & 1.00 \\
\hline
\end{tabular}

geoeducational value can be observed: (i) succession of vegetation on the quarry walls, which reduces the legibility of exposures (e.g. Rąblów2); (ii) litter and junk in the quarries (e.g. Kopiec); (iii) limited access due to nature conservation (bat habitats) or private land ownership (e.g. Bochotnica6). Further work on the establishment of the Geopark and preparation of a management plan for the geotourist area will make it possible to adapt the quarries to the needs of geoeducation. So far, unfortunately, local governments and the tourism industry have not recognised the potential arising from high geoheritage values and the benefits resulting from establishing the Geopark in the future. No strategy for the geoconservation of any of the quarries has been prepared so far, and their geological features which become less and less clearly exposed due to processes of natural succession (Fig. 8).

Extending protection over the quarries in the form of nature reserves is difficult in Poland because, according to the law, "a nature reserve encompasses areas preserved in natural or little changed state" (Ustawa z dnia 16 kwietnia 2004 r. o ochronie przyrody, Wierzbowski et al. 2017). The establishment of new forms of protection, including those in the abandoned 


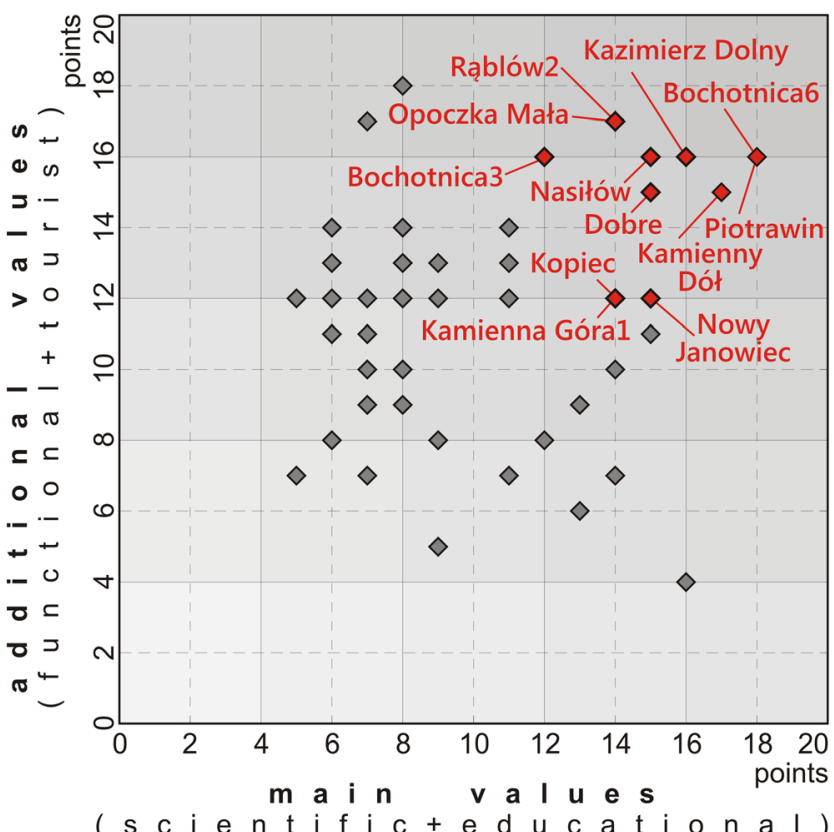

Fig. 7 The relationship between the main and additional values in the quarries of Małopolska Vistula River Gap (the names used on the figure refer to the quarries of high geoeducational potential (vide Fig. 4 and Table 6)

quarries, seems to be rather unlikely. Local governments and the public do not welcome such measures because, in their opinion, they limit the possibilities of economic and tourist development. Still, it seems that the threat of degradation does not occur in the case of the unused solid rock quarries in the area under study. Furthermore, no major threats are observed with regard to the uncontrolled extraction of raw materials and collection of minerals and fossils. In our opinion, the possibility of controlled search for interesting rocks and fossils (during classes) is an advantage. Such actions are allowed by the Polish law as long as they are not carried out for commercial purposes.

A different situation occurs with non-consolidated sediments: during their active extraction, the possibilities of using them for educational purposes are limited or non-existent. On the other hand, the discontinuation of extraction leads to the gradual loss of legibility of the structures and the constituent rocks as a result of natural processes, i.e. the sliding of the material down the walls and the succession of vegetation (Fig. 8). For example, such a situation occurred in the interesting exposure of fluvioglacial sediments in Rablów2. It seems that the solution proposed by Prosser (2018), i.e. conducting extraction in a way that would enable the preservation of geoheritage and enhance the geoeducational value of these sites, would be the best solution for quarries of non-consolidated rocks.

The chamber (underground) quarry in Bochotnica (geosite Bochotnica6) (Fig. 1) is the only quarry under protection in the study area, and this protection concerns bats inhabiting the underground chambers rather than assets of abiotic nature. The establishment of a Natura 2000 bat sanctuary resulted in the restriction of access to the wall where the K-Pg boundary is exposed. That move was unfavourable from the perspective of geoducation development, but, on the other hand, it has preserved the exposures and has helped protect the quarry itself from degradation.

The highly rated quarries located within the study area enable the exploration of two main geological topics: (i) Life in the Cretaceous sea and traces of the global event (meteorite impact) that caused the extinction of dinosaurs (e.g. Bochotnica6, Kamienny Dół); (ii) Ice Age and loess landscape history (e.g. Rąblów2, Nowy Janowiec). Based on these quarries, one can follow a full record of the evolution of a sea basin: from mid-Cretaceous transgression, to the regression at the end of the Cretaceous (Harasimiuk et al. 2011).

At present, quarries in the Małopolska Vistula River Gap are used for formal education to a limited extent (mostly for field classes for students). At the same time, a questionnaire survey shows that only 30-40\% of the students of the Faculty of Earth Sciences and Spatial Management at Maria Curie-Skłodowska University (MCSU) in Lublin have visited the scientifically valuable quarries in the northern part of the study area

Table 8 Development of geoeducation and geotourism in quarries-SWOT analysis

\begin{tabular}{lll}
\hline & Helpful & Harmful \\
\hline Internal & $\begin{array}{l}\text { Strengths } \\
\text { - High scientific and educational value } \\
\text { of some quarries }\end{array}$ & Weaknesses \\
& - Existing scientific study on the potential Geopark & - Lack of educational geotourism products \\
& - Intense tourist traffic in the N part of the studied area & - Lack of qualified tourist guides \\
& - Easy access to almost all sites & - Very limited number of tourists in some sites \\
External & Opportunities & - Diversified ownership of quarries \\
& - Development of educational products & \\
& - Beginning of efforts to establish a Geopark & Threats \\
& - Increasing interest in active and alternative tourism & - Lack of support for activities focused on geotourism \\
& & - Lack of agreement between local governments \\
& & concerning the development of tourism/geotourism \\
& & - Lack of knowledge and interest among tourists \\
\end{tabular}



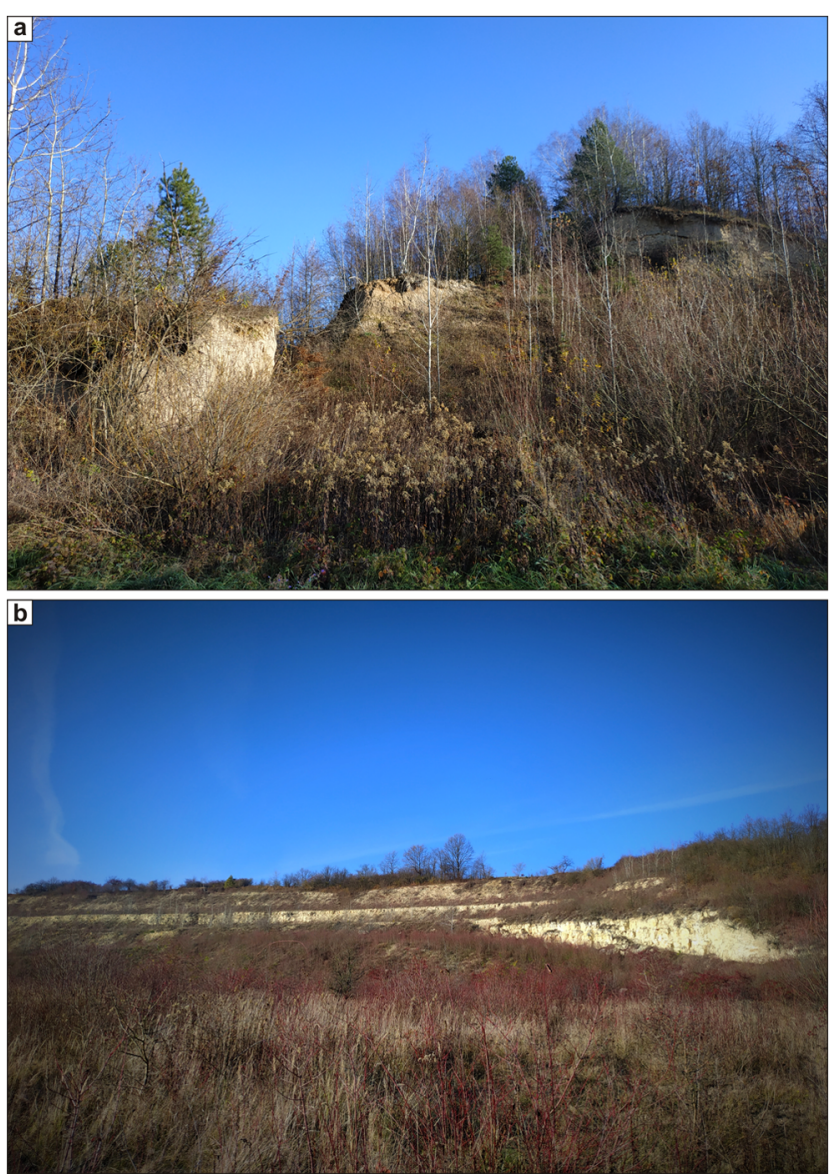

Fig. 8 Succession of vegetation and destruction of walls as a result of mass wasting occurring in the abandoned quarries in Rąblów2 (a) and Nasiłów (b) (all photographs by G. Gajek)

(Bochotnica6, Kazimierz Dolny). Only one of the quarries, i.e. the quarry in Bochotnica6, has been included in the Geotourist Map of Poland 1:750,000. So far, the main problem preventing the possibility of a broader use of the quarries has been the insufficient understanding of their educational value and the lack of appropriate educational material (guide books, trail cards, pamphlets) that could be used during field classes. The first efforts in this respect are being made at the Faculty of Earth Sciences and Spatial Management, MCSU in Lublin: (i) funds have been obtained for conducting field classes for primary school pupils; the classes will be conducted by the authors of this paper; (ii) the first virtual geotourist trails featuring quarries in the Kazimierz Dolny area are under preparation as part of a master thesis; (iii) a $\mathrm{PhD}$ thesis (currently under preparation) will feature field-trip lesson plans for secondary school pupils.

Geological research conducted in the Małopolska Vistula River Gap area for several decades has produced a detailed documentation of the geoheritage, offering a good basis for the preparation of themed educational products featuring rock exposures in the area. The guidebooks published so far (only 6 in Polish) present various selected aspects of the environment, including geoheritage (Pożaryska and Pożaryski 1951;
Pawłowski 1995, 1999; Kowalczyk and Pawłowski 1998; Pawłowski et al. 2008). They contain proposals of 16 field trip trails and 13 educational paths. Some of these trails have been marked (mainly educational paths), but only a few possess information boards. The Natural History Museum in Kazimierz Dolny plays a huge role in geoeducation and promotion of geoheritage. Each year, the Museum is visited by 20-30 thousand people (mainly on school trips). Alongside multimedia exhibitions devoted to the geology of the Małopolska Vistula River Gap, the Museum also offers natural history trips featuring selected geological exposures.

A more extensive use of rock outcrops for informal and formal education would be facilitated by the development of educational products such as virtual geological tours, heritage e-trails, earth caching and apps that are among the main teaching methods in many European geoparks (Zecha and Regelous 2018). For university education on geoheritage, innovative tools such as a digital learning platform can be used (Reynard et al. 2016). There are also interesting educational programs promoting geoeducation for people with functional disability (Henriques et al. 2018).

Building the awareness of geoheritage in local communities is an important aspect of work related to the popularity of abiotic resources and making them accessible. Such work is performed mainly by geoparks (Dowling 2011). There are also examples of actions taken by local organisations in cooperation with local government and scientific bodies and local communities that are aimed at building the brand as local or regional geoheritage (Migoń and Pijet-Migoń 2016). For example, an attempt to promote loess geoheritage in the study area has been undertaken by the "Kraina Lessowych Wąwozów" (Engl. "Land of Loess Gullies") Local Action Group.

\section{Conclusions}

1. The assessment carried out in this study shows that the quarries located in the Małopolska Vistula River Gap have a high geoeducational potential (scientific and educational value) enabling the observation of various natural processes based on participation-based learning methods. Currently, this potential is not sufficiently exploited for educational purposes due to lack of educational materials.

2. The distribution of the most valuable quarries, from the perspective of geoeducation, is uneven. Most are concentrated in the northern part of the study area. At the same time, they are popular tourist attractions. This last offers an opportunity for a fast development of multi-themed, informal and formal geoeducation in this part of the study area thanks to the high scientific value of the quarries.

3. The development of geoeducation in this area would surely be fostered by measures that would lead to the 
establishment of the Geopark. Quarries with the highest value can be the basis for the development of modern and attractive geotourism products that could be used at various levels of education. They should be the primary focus of the promotion work conducted among tour organizers in this region.

4. The scope of measures leading to a better use of the quarries for geoeducation and geotourism is varied. It seems indispensable to intensify actions promoting the geoeducational value of the quarries. Furthermore, most of the quarries in the southern part of the area require more scientific research so that these interesting quarries can become destinations for formal education.

5. From the perspective of the educational function, it is important to improve safety for visitors in all the quarries under study. Furthermore, the growth of vegetation and decreased legibility of geoheritage features will be a problem in some of the quarries as time goes by. Therefore, a management planning should be put in place to prevent these negative phenomena.

Acknowledgements The authors would like to thank reviewers and guest editor for their insightful comments on the paper, as these comments led us to the improvement of the work.

Funding information The study was financed with research funds from the Faculty of Earth Sciences and Spatial Management, Maria CurieSkłodowska University in Lublin.

Open Access This article is distributed under the terms of the Creative Commons Attribution 4.0 International License (http:// creativecommons.org/licenses/by/4.0/), which permits unrestricted use, distribution, and reproduction in any medium, provided you give appropriate credit to the original author(s) and the source, provide a link to the Creative Commons license, and indicate if changes were made.

\section{References}

Abdel-Gawad GI (1986) Maastrichtian non-cephalopod mollusks (Scaphopoda, Gastropoda and Bivalvia) of the Middle Vistula Valley, Central Poland. Acta Geol Pol 36:69-224

Alexandrowicz Z (2006) Framework of European quarries in Poland. Nat Conserv 62:63-87

Bąbelewska A, Musielińska R, Śliwińska-Wyrzychowska A, Bogdanowicz M, Witkowska E (2014) Edukacyjna rola nieczynnego kamieniołomu "Lipówka" w Rudnikach koło Częstochowy. Prace Komisji Krajobrazu Kulturowego 26:57-66

Baczyńska E, Lorenc M (2012) Problemowe kamieniołomy - proste rozwiązania. In: Zagożdżon P, Madziarz M (eds) Dzieje górnictwa - element europejskiego dziedzictwa kultury, Wrocław, pp 7-15

Baczyńska E, Lorenc MW, Kaźmierczak U (2018) The landscape attractiveness of abandoned quarries. Geoheritage 10:271-285

Beranova L, Martin B, Raška P (2017) Assessing the geotourism potential of abandoned quarries with multitemporal data (České Středohoří Mts., Czechia). GeoScape 11:93-111

Berrocal-Casero M, Arribas M, Moratalla JJ (2018) Didactic and divulgative resources of the Middle Triassic vertebrate tracksite of
Los Arroturos (Province of Guadalajara, Spain). Geoheritage 10: 375-384

Bobiński W, Gawlikowska E, Kłonowski M (1999) Important geosites of the Polish Sudetes. Polish Geological Institute, Special Papers 2:19 25

Brilha J (2016) Inventory and quantitative assessment of quarries and geodiversity sites: a review. Geoheritage 8:119-134

Dmytrowski P, Kicińska A (2011) Waloryzacja geoturystyczna obiektów przyrody nieożywionej i jej znaczenie w perspektywie rozwoju geoparków. Problemy Ekologii Krajobrazu 29:11-20

Dolecki L, Kołodziej T, Mroczek P (2004) Rozmieszczenie lessu na Wyżynie Lubelskiej i Roztoczu, główne stanowiska badawcze i stan badań. Annales UMCS, B 59:9-35

Dowling RK (2011) Geotourism's global growth. Geoheritage 3:1-13

Fermeli G, Hevia GM, Koutsouveli A, Dermitzakis M, Calonge A, Steininger F, D’Arpa C, Di Patti C (2015) Geoscience teaching and student interest in secondary schools-preliminary results from an interest research in Greece, Spain and Italy. Geoheritage 7:13-24

Feuillet T, Sourp E (2011) Geomorphological heritage of the Pyrenees National Park (France): assessment, clustering and promotion of geomorphosites. Geoheritage 3:151-162

Hansen HJ, Rasmussen KL, Gwozd R, Hansen JM, Radwański A (1989) The Cretaceous/Tertiary boundary in central Poland. Acta Geol Pol 39:1-12

Harasimiuk M (1980) Rzeźba strukturalna Wyżyny Lubelskiej i Roztocza. UMCS, Lublin

Harasimiuk M, Henkiel A (1978) Wpływ budowy geologicznej i rzeźby podłoża na ukształtowanie pokrywy lessowej w zachodniej części Płaskowyżu Nałęczowskiego. Annales UMCS. B 30(31):55-80

Harasimiuk M, Domonik A, Machalski M, Pinińska J, Warowna J, Szymkowiak A (2011) Małopolski Przełom Wisły - projekt geoparku. Prz Geol 59:405-416

Henriques MH, Canales ML, García-Frank A, Gomez-Heras M (2018) Accessible geoparks in Iberia: a challenge to promote geotourism and education for sustainable development. Geoheritage 11:471484. https://doi.org/10.1007/s12371-018-0300-5

Hose TA (1995) Selling the story of Britain's stone. Environ Interpretation 10:16-17

Kasprowska-Nowak K, Marek A (2019) Geotourism valorisation of selected quarries of Kłodzko Region and Cieszyn Foothills. Quaestiones Geographicae 38:41-51

Kin A, Niedźwiedzki R (2012) First record of the puzosiine ammonite genus Pachydesmoceras from the Middle and Upper Turonian of Poland. Cretac Res 22:15-20

Komorowski A, Adamczak M, Gajek G, Przedpełski Ł, Lorenc MW (2016) Kopalnia fosforytów w Annopolu - dziedzictwo kulturowe i geologiczne w świetle badań TLS. I Warsztaty "Dziedzictwo i Historia Górnictwa", Złoty Stok (Poland), 14-15.04.2016, Materiały: $24-25$

Kondracki J (2000) Geografia regionalna Polski. PWN, Warszawa

Kowalczyk L, Pawłowski A, (1998) Przewodnik po ścieżkach dydaktycznych Kazimierskiego Parku Krajobrazowego cz. 2. Zarząd Zespoły Lubelskich Parków Krajobrazowych, Lublin

Krzywiec P, Wybraniec S (2007) Budowa geologiczna północnowschodniej części zapadliska przedkarpackiego (SE Polska) w świetle danych geofizycznych. In: Harasimiuk M (ed) Budowa geologiczna regionu lubelskiego i problemy ochrony litosfery. Uniwersytet Marii Curie-Skłodowskiej w Lublinie, Lublin, pp 7586

Kubalíková L (2013) Geomorphosite assesment for geotourism purposes. Czech J Tourism 2:80-104

Kubalíková L, Kirchner K (2016) Geosite and geomorphosite assessment as a tool for geoconservation and geotourism purposes: a case study from Vizovická vrchovina highland (eastern part of the Czech Republic). Geoheritage 8:5-14 
Kukla G (1977) Pleistocene land-sea correlations 1. Europe. Earth Sci Rev 13

Lorenc MW, Gajek G, Komorowski A (2016) The old phosphorite mine in Annopol (Poland): an example of mining heritage and an unique palaeontologic site. 11th International Mining History Congress "Mines: History and Influence in Industrial and Social Development of Mining Communities", Linares (Spain), 611.09.2016, Book of Abstracts: 28-29

Machalski M (1998) Granica kreda-trzeciorzęd w przełomie Wisły. Prz Geol 46:1153-1161

Machalski M (2005a) The youngest Maastrichtian ammonite faunas from Poland and their dating by scaphitids. Cretac Res 26:813-836

Machalski M (2005b) Late Maastrichtian and earliest Danian scaphitid ammonites from central Europe: taxonomy, evolution, and extinction. Acta Palaeontol Pol 50:653-696

Machalski M (2007) Wydarzenia na granicy kreda-paleogen w Małopolskim Przełomie Wisły. In: Harasimiuk M, BrzezińskaWójcik T, Dobrowolski R, Mroczek P, Warowna J (eds) Budowa geologiczna regionu lubelskiego i problemy ochrony litosfery. Uniwersytet Marii Curie-Skłodowskiej w Lublinie, Lublin, pp 229-234

Machalski M (2012) Stratigraphically important ammonites from the Campanian-Maastrichtian boundary interval of the Middle Vistula River section, central Poland. Acta Geol Pol 62:91-116

Machalski M, Jagt JWM (2018) A new Danian echinoid assemblage from the Greensand in the Kazimierz Dolny area, central Poland: taxonomy, taphonomy and sedimentological implications. Acta Geol Pol 68:571-596

Machalski M, Kennedy WJ (2013) Oyster-bioimmured ammonites from the Upper Albian of Annopol, Poland: stratigraphic and palaeobiogeographic implications. Acta Geol Pol 63:545-554

Machalski M, Liwiński W (2018) Geotourism as a vehicle for geoconservation: the case of an abandoned phosphorite mine at Annopol, Poland. In: Głowniak E, Wasiłowska A, Leonowicz P (ed) Geoheritage and Conservation: Modern Approaches and Applications Towards the 2030 Agenda. 9th ProGEO Symposium, Chęciny, Poland, 25-28th June 2018 Programme and abstract book. Faculty of Geology, University of Warsaw, pp 50-51

Machalski M, Komorowski A, Harasimiuk M (2009) Nowe perspektywy poszukiwań morskich kregowców kredowych w nieczynnej kopalni fosforytów w Annopolu nad Wisłą. Prz Geol 57:638-641

Magagna A, Ferrero E, Giardino M, Lozar F, Perotti L (2013) A selection of geological tours for promoting the Italian geological heritage in the secondary schools. Geoheritage 5:265-273

Marks L, Dzierżek J, Janiszewski R, Kaczorowski J, Lindner L, Majecka A, Makos M, Szymanek M, Tołoczko-Pasek A, Woronko B (2016) Quaternary stratigraphy and palaeogeography of Poland. Acta Geol Pol 66(3):403-427

Maruszczak H (1991) Ogólna charakterystyka lessów w Polsce. In: Maruszczak H (ed) Podstawowe profile lessów w Polsce. A. Uniwersytet Marii-Curie Skłodowskiej w Lublinie, Lublin, pp 1-12

Maruszczak H (1995) Glacial cycles of loess accumulation in Poland during the last $400 \mathrm{ka}$ and global rhythms of paleogeographical events. Annales UMCS, B 50:127-156

Maruszczak H (2000) Definicja i klasyfikacja lessów oraz utworów lessopodobnych. Prz Geol 48:580-586

Migoń P, Pijet-Migoń E (2016) Overlooked geomorphological component of volcanic geoheritage: diversity and perspectives for tourism industry, Pogórze Kaczawskie egion, SW Poland. Geoheritage 8: 333-350

Narkiewicz M, Dadlez R (2008) Geologiczna regionalizacja Polski zasady ogólne i schemat podziału w planie podkenozoicznym i podpermskim. Prz Geol 56:391-397

Neches IM (2013) From geomorphosite evaluation to geotourism interpretation. Case study: the Sphinx of Romanian's Southern Carpathians. GeoJ Tourism Geosites 12:145-162
Nita J (2012) Quarries in landscape and geotourism. Geogr Pol 85:5-12 Oszczypko N (1996) Mioceńska dynamika polskiej części zapadliska przedkarpackiego. Prz Geol 44:1007-1018

Panizza M (2001) Geomorphosites: concepts, methods and examples of geomorphological survey. Chin Sci Bull 46:4-5

Pawłowski A (1995) Przewodnik po ścieżkach dydaktycznych Kazimierskiego Parku Krajobrazowego 1. Zarząd Zespoły Lubelskich Parków Krajobrazowych, Lublin

Pawłowski A (1999) Wrzelowiecki Park Krajobrazowy przewodnik przyrodniczy. Informator. Zarząd Zespołu Lubelskich Parków Krajobrazowych, Lublin

Pawłowski A, Rodzik J, Wawer K (2008) Szlak lessowych wąwozów. LOT "Kraina lessowych wąwozów", Nałęczów

Pecsi M (1990) Loess is not just the accumulation of dust. Quat Int 7(8): $1-21$

Petersen J (2002) The role of roadcuts, quarries, and other artificial exposures in geomorphology education. Geomorphology 47:289-301

Pinińska J (2007) Górnictwo skalne jako geologiczny składnik dziedzictwa kulturowego regionu lubelskiego. Biuletyn Państwowego Instytutu Geologicznego 422:97-112

Pożaryska K (1952) Zagadnienia sedymentologiczne górnego mastrychtu i danu okolic Puław (The sedimentological Problems of Upper Maestrichtian and Danian of the Puławy environment, Middle Vistula). Biuletyn Państwowego Instytutu Geologicznego 81:1-104

Pożaryska K, Pożaryski W (1951) Przewodnik geologiczny po Kazimierzu i okolicy. Wydawnictwo Muzeum Ziemi, Warszawa

Pożaryski W (1997) Tektonika powaryscyjska obszaru świętokrzyskolubelskiego na tle struktury podłoża. Prz Geol 45:1265-1270

Pożaryski W, Maruszczak H, Lindner L (1994) Chronostratygrafia osadów plejstoceńskich i rozwój doliny Wisły środkowej ze szczególnym uwzględnieniem przełomu przez wyżyny południowopolskie. Prace PIG 147:1-58

Pralong JP (2005) A method for assessing tourist potential and use of geomorphological sites. Géomorphologie: Relief, Processus, Environnement 11:189-196

Prosser CD (2018) Geoconservation, quarrying and mining: opportunities and challenges illustrated through working in partnership with the mineral extraction industry in England. Geoheritage 10:259-270

Reynard E, Fontana G, Kozlik L, Scapozza C (2007) A method for assessing scientific and additional values of geomorphosites. Geographia Helvetica 62:148-158

Reynard E, Coratza P, Cayla N, Clivaz M, Comănescu L, Darbellay L, Giusti C, Grecu F, Hobléa F, Pereira P (2016) InterGEO: a digital platform for university education on geomorphological heritage. Geoheritage 10:645-657. https://doi.org/10.1007/s12371-0180298-8

Rogowski M (2016) The potential of the Sudetes Mountains for the development of geotouristic products. Geotourism 46-47:59-80

Różycka M, Migoń P (2018) Customer-oriented evaluation of geoheritage - on the example of volcanic geosites in the West Sudetes, SW Poland. Geoheritage 10:23-37

Słodkowska B (2003) Wstępne dane o badaniach fitoplanktonu w Kamiennym Dole (okolice Kazimierza Dolnego). Prz Geol 51: 1075-1078

Sobala M, Pukowiec K (2014) Stan zagospodarowania nieczynnych kamieniołomów na terenie Beskidu Śląskiego i Żywieckiego a polityka przestrzenna gmin. Prace Komisji Krajobrazu Kulturowego 26:127-138

Solarska A, Hose TA, Djordjije A, Vasiljević DA, Mroczek P, Jary Z, Marković SB, Widawski K (2013) Geodiversity of the loess regions in Poland: inventory, geoconservation issues, and geotourism potential. Quat Int 296:68-81

Stefano M, Paolo S (2017) Abandoned quarries and geotourism: an opportunity for the Salento Quarry District (Apulia, Southern Italy). Geoheritage 9:463-477 
Świerczewska-Gładysz E (2006) Late Cretaceous siliceous sponges from the Middle Vistula River valey (Central Poland) and their palaeoecological significance. Ann Soc Geol Pol 76:227-296

Świerczewska-Gładysz E, Olszewska-Nejbert D (2006) Pochodzenie sfosfatyzowanych gąbek z warstwy dańskiego piaskowca glaukonitowego z Nasiłowa (dolina środkowej Wisły). Prz Geol 54:710-719

Urban J, Wróblewski T (1999) Representative geosites of the Góry Świętokrzyskie (Holy Cross Mts.) and the Nida Basin, Central Poland. Polish Geological Institute. Special Papers 2:61-70

Ustawa z dnia 16 kwietnia 2004 r. o ochronie przyrody (Dz.U. 2018 poz. 1614)

Ustawa z dnia 9 czerwca 2011 r. - Prawo geologiczne i górnicze (Dz.U.2017.0.2126)

Vasiljević DA, Marković SB, Hose TA, Smalley I, O'Hara-Dhand K, Basarin B, Lukić T, Vujićić MD (2011) Loess towards (geo) tourism - proposed application on loess in Vojvodina region (North Serbia). Acta Geogr Slov 51(2):390-406

Vujičić MD, Vasiljević DA, Marković SB, Hose TA, Lukić T, Hadžić O, Janićević S (2011) Preliminary geosite assessment model (GAM) and its application on Fruska Gora Mountain, potential geotourism destination of Serbia. Acta Geogr Slov 51(2):361-377

Walaszczyk I (1992) Turonian through Santonian deposits of the Central Polish Uplands; their facies development, inoceramid paleontology and stratigraphy. Acta Geol Pol 42:1-122

Walaszczyk I (2004) Inoceramids and inoceramid biostratigraphy of the Upper Campanian to basal Maastrichtian of the Middle Vistula River Section, central Poland. Acta Geol Pol 54:95-168
Walaszczyk I, Ciesieliński S, Sylwestrzak H (1999) Selected geosites of Cretaceous deposits in Central and Eastern Poland. Polish Geological Institute, Special Papers 2:71-76

Warowna J, Zgłobicki W, Kołodyńska-Gawrysiak R, Gajek G, Gawrysiak L, Telecka M (2016) Geotourist values of loess geoheritage within the planned Geopark Małopolska Vistula River Gap, E Poland. Quat Int 399:46-57

Wierzbowski A, Krzeczyńska M, Woźniak P (2017) Ochrona starych kamieniołomów jako obiektów przyrodniczych o walorach naukowych, edukacyjnych i geoturystycznych - teoria a praktyka. Hereditas Minariorum 4:135-151

Wróblewski T (2000) Ochrona georóżnorodności w regionie świętokrzyskim. Państwowy Instytut Geologiczny, Warszawa

Wysocka A, Jasionowski M, Peryt T (2007) Miocene of the Roztocze Hills. Biuletyn Państwowego Instytutu Geologicznego 422:79-96

Żarski M, Jakubowski G, Gawor-Biedowa E (1998) The first Polish find of Lower Paleocene crocodille Thoracosaurus leidy, 1852: geological and palaeontological description. Geol Quart 42:141-160

Zecha S, Regelous A (2018) Promoting geodiversity education by using earth caching in national geoparks. Geoheritage 10:637-643. https:// doi.org/10.1007/s12371-018-0280-5

Zgłobicki W, Gawrysiak L, Kołodyńska-Gawrysiak R (2015) Gully erosion as a natural hazard: the educational role of geotourism. Nat Hazards 79(Supplement 1):159-181

Zgłobicki W, Poesen J, Cohen M, Del Monte M, García-Ruiz JM, Ionita I, Niacsu L, Machová Z, Martín-Duque JF, Nadal-Romero E, Pica A, Rey R, Solé-Benet A, Stankoviansky M, Stolz C, Torri D, Soms J, Vergari F (2019) The potential of permanent gullies in Europe as geomorphosites. Geoheritage 11:217-239. https://doi.org/10.1007/ s12371-017-0252-1 